\title{
ANALISIS LAPORAN KEUANGAN UNTUK MENILAI PRESTASI PERUSAHAAN MANUFAKTUR SUB SEKTOR SEMEN YANG TERDAFTAR DI BURSA EFEK INDONESIA
}

\author{
Melvi Yansi \\ Program Studi Manajemen Universitas Prof.Dr.Hazairin,SH Bengkulu \\ melviyansi215@gmail.com
}

\begin{abstract}
ABSTRAK
Melvi Yansi: Penelitian ini bertujuan untuk dapat lebih mengetahui prestasi kerja perusahaan semen yang dinilai dari laporan keuangan, dengan mengambil sampel dua perusahaan semen yang terdaftar di bursa efek Indonesia yaitu PT. Indocement Tunggal Perkasa,Tbk dan PT. Holcim,Tbk dari tahun 2014 sampai dengan tahun 2015. Penelitian ini bersifat komparatif, berdasarkan ke empat rasio keuangan dapat menunjukkan bahwa kinerja keuangan PT. Indocement Tunggal Perkasa,Tbk sudah cukup baik hanya untuk rasio aktivitas dan ROE serta ROI saja yang masih kurang baik, sedangkan kinerja keuangan PT. Holcim,Tbk masing kurang baik. PT. Indocement Tunggal Perkasa,Tbk diharapkan untuk dapat mempertahankan kinerja keuangan yang telah ada dan lebih ditingkatkan lagi dalam pemanfaatan aktiva lancar, sedangkan untuk PT. Holcim,Tbk untuk dapat meningkatkan lagi kinerja keuangan yang ada dengan lebik baik lagi pengelolaan kas perusahaan yang nantinya akan digunakan membayar kewajiban perusahaan.
\end{abstract}

\section{ABSTRACT}

Melvi Yansi: This study aims to better know the performance of cement companies were assessed from the financial statements, by taking samples of the two cement companies listed on stock exchanges of Indonesia, namely PT. Indocement Tunggal Perkasa Tbk and PT. Holcim, Tbk from 2014 until 2015. This research is comparative, according to four financial ratios may indicate that the financial performance. Indocement Tunggal Perkasa, Tbk is good enough only for the activity ratio and ROE, and ROI are still not good, while financial performance. Holcim, respectively Tbk unfavorable. PT. Indocement Tunggal Perkasa, Tbk expected to be able to sustain the financial performance of existing and further enhanced in the utilization of current assets, whereas for PT. Holcim, Tbk to be able to improve the financial performance of existing again with lebik better cash management company that will be used to pay liabilities of the company.

Key Words: Financial Statements, Financial Ratios.

\section{PENDAHULUAN}

Dalam era globalisasi persaingan perusahaan semakin kuat mengakibatkan perusahaan untuk lebih gencar meningkatkan kemampuan perusahaan khususnya finansial. Kemampuan perusahaan untuk dapat meningkatkan kemampuan finansial dapat dilihat dari laporan keuangan setiap tahunnya. Apabila perusahaan tidak dapat mengontrol keuangan maka akan mengakibatkan kebangkrutan,

Dalam menilai prestasi perusahaan dapat dilihat dari kinerja keuangan,yang tercermin dalam laporan keuangan. Dalam menganalisis laporan keuangan biasanya menggunakan rasio likuiditas, rasio solvabilitas, rasio aktivitas dan rasio rentabilitas. Perusahaan semen yang terdaftar di BEI ada sebanyak enam perusahaan, untuk dapat bersaing perlu adanya penilai kinerja keuangannya.

\section{TINJAUAN PUSTAKA \\ Laporan Keuangan}

Kamaludin dan Indriani. R (2011. 34 ) mendefenisikan laporan keuangan merupakan hasil akhir dari suatu proses pencatatan yang merupakan suatu ringkasan dari transaksi keuangan yang terjadi selama tahun buku yang bersangkutan. 
Laporan keuangan yang diterbitkan biasanya terbagi menjadi dua jenis informasi. Bagian pertama adalah bagian verbal yang menyajikan hasil perusahaan selama satu tahun yang lalu dan membahas perkembangan baru yang akan mempengaruhi operasi perusahaan, laporan yang akan muncul berupa annual report. Bagian kedua adalah laporan tahunan yang terdiri dari empat laporan keuangan dasar, yaitu: neraca, laporan laba rugi, laporan laba ditahan dan laporan arus kas.

Kasmir (2008: 28) mengemukakan secara umum ada 5 macam jenis laporan keuangan yang biasa disusun, yaitu
a. Neraca
b. Laporan laba rugi
c. Laporan perubahan modal,
d. Laporan arus kas
e. Laporan revisi atas laporan keuangan

\section{Analisis Laporan Keuangan}

Menurut Wild (2005:3), Analisis laporan keuangan (financial statement analysis) merupakan aplikasi dari alat dan teknik analisis untuk laporan keuangan bertujuan umum dan data-data yang berkaitan untuk menghasilkan estimasi dan kesimpulan yang bermanfaat dalam analisis bisnis.

\section{Analisis Rasio Keuangan}

James C Van Horne (2008:104) mengemukakan pengertian rasio keuangan merupakan indeks yang menghubungkan dua angka akuntansi dan diperoleh dengan membagi satu angka dengan angka lainnya.

Dengan demikian Analisis rasio keuangan dapat juga diartikan membandingkan angka-angka yang ada dalam laporan keuangan untuk mengetahui posisi keuangan suatu perusahaan serta menilai kinerja manajemen dalam suatu periode tertentu. yaitu :

Rasio keuangan perusahaan dapat dikelompokkan menjadi lima kelompok (Rahardjo (2007: 104)

1. Rasio Likuiditas (liquidity ratio),

a. Current Ratio

Digunakan untuk mengetahui kemampuan perusahaan dalam memenuhi kewajiban jangka pendek,karena semua aktiva lancar dikonversikan kedalam kas.

b. Quick Ratio

Untuk mengetahui kemampuan aktiva lancar yang paling likuid dan piutang mampu menutupi hutang lancar.

c. Absolute Liquid Ratio (ALR)

Untuk mengetahui kemampuan perusahaan dalam mendanai perusahaan dengan menggunakan kas dan setara kas terhadap hutang lancar.

2. Rasio Solvabilitas,.

Rasio solvabilitas merupakan rasio yang digunakan untuk mengukur sejauhmana aktiva perusahaan dibiayai dengan utang. Artinya berapa beban utang yang ditanggung perusahaan dengan aktivanya. Dalam arti luas dikatakan rasio solvabilitas dugunakan untuk membayar seluruh kewajibannya,baik jangka pendek maupun jangka panjang apabila perusahaan di likuidasi.

Rasio leverage yang biasa digunakan adalah :
a. Debt To Equity Ratio (DER)
b. Total Asset To Equity Ratio
c. Fixed Asset To Equity Ratio
d. Current Asset To Equity Ratio
e. Receivable To Equity Ratio.

3. Rasio Aktivitas

Merupakan rasio yang digunakan untuk mengukur efektivitas perusahaan dalam menggunakan aktiva yang dimilikinya. Penggunaan rasio aktivitas dengan cara membandingkan antara tingkat penjualan dengan investasi dalam aktiva untuk satu periode.

Rasio aktivitas yang biasa digunakan adalah :
a. Sales To Receivable
b. Sales To Current Asset
c. Sales To Fixed Asset
d. Sales To Total Asset

4. Rasio Profitabilitas dan Rentabilitas, 
Rasio profitabilitas menunjukkan gambaran tentang tingkat efektivitas pengelolaan perusahaan dalam menghasilkan laba. Rasio ini sebagai ukuran apakah pemilik atau pemegang saham dapat memperoleh tingkat pengembalian yang pantas atas investasiny. Ukuran yang biasa digunakan adalah:
a. Net Profit Margin (NPM)
b. Return on Investment (ROI)
c. Return On Equity (ROE)

\section{METODE PENELITIAN}

Penelitian ini menggunakan penelitian komparatif, yang membandingkan laporan keuangan PT. Indocement Tunggal Perkasa,Tbk dengan PT Holcim,Tbk, tahun 2014 - 2015.

\section{HASIL DAN PEMBAHASAN Analisis Rasio Likuiditas}

\section{Current Ratio}

Tabel 1 menunjukkan bahwa PT. Indocement Tunggal Perkasa, Tbk untuk tahun 2014 sebesar 4.94 dan pada tahun 2015 terjadi penurunan nilai rasio menjadi 4.89. walau demikian perusahaan telah dianggap baik karena telah dapat memenuhi kewajiban jangka pendek dan berada diatas rasio industri. Sedangkan PT. Holcim. Tbk untuk tahun 2014 sebesar 0.60 dan pada tahun 2015 meningkat menjadi 0.69 , walau demikian masih dibawah rata-rata industri.

Tabel 1. Current Ratio

\begin{tabular}{|c|c|c|}
\hline Tahun & $\begin{array}{c}\text { PT. Indocement Tunggal } \\
\text { Perkasa, Tbk }\end{array}$ & PT. Holcim, Tbk \\
\hline 2014 & 4.93 & 0.60 \\
\hline 2015 & 4.89 & 0.69 \\
\hline
\end{tabular}

Sumber : Data yang diolah

\section{Quick Ratio}

Dari Tabel 2 dapat diambil kesimpulan PT. Indocement Tunggal Perkasa. Tbk dianggap baik dalam membiayai hutang lancar dengan aktiva likuid dan piutang. karena diatas rata-rata industri. sedangkan PT. Holcim. Tbk dianggap buruk dalam membayar hurang lancar dengan aset lancar tanpa persediaan. karena dibawah rata-rata industri

Tabel 2. Quick Ratio

\begin{tabular}{|c|c|c|}
\hline Tahun & $\begin{array}{c}\text { PT. Indocement Tunggal Perkasa, } \\
\text { Tbk }\end{array}$ & PT. Holcim, Tbk \\
\hline 2014 & 4.27 & 0.37 \\
\hline 2015 & 4.16 & 0.21 \\
\hline
\end{tabular}

Sumber : Data yang diolah

3. Absolute Liquid Ratio

Tabel 3 menunjukkan PT. Indocement Tunggal Perkasa. Tbk pada tahun 2014 sebesar 3.45 dan pada tahu 2015 menurun menjadi 3.22. Dengan demikian kemampuan perusahaan dalam memenuhi hutang jangka pendek dengan aktiva likuid dan persediaan masih kurang baik.karena berada dibawah rasio industri. begitu juga dengan PT. Holcim. Tbk dimana tahun 2014 sebesar 0.06 dan tahun 2015 sebesar 0.07 .

Tabel 3. Absolute Liquid Ratio

\begin{tabular}{|c|c|c|}
\hline Tahun & $\begin{array}{c}\text { PT. Indocement Tunggal Perkasa. } \\
\text { Tbk }\end{array}$ & PT. Holcim. Tbk \\
\hline 2014 & 3.45 & 0.06 \\
\hline 2015 & 3.22 & 0.07 \\
\hline
\end{tabular}

Sumber : Data yang diolah 


\section{Analisis Rasio Solvabilitas}

1. Debt to Equty Ratio

Dari Tabel 4 dapat lihat bahwa PT. Indocement Tunggal Perkasa. Tbk untuk kebutuhan dana dibelanjai dengan hutang sudah cukup baik sebaliknya untuk PT. Holcim. Tbk masih kurang baik.

Tabel 4. Debt to Equty Ratio

\begin{tabular}{|c|c|c|}
\hline Tahun & PT. Indocement Tunggal Perkasa. Tbk & PT. Holcim. Tbk \\
\hline 2014 & 0.17 & 0.96 \\
\hline 2015 & 0.16 & 1.05 \\
\hline
\end{tabular}

Sumber : Data yang diolah

2. Total Asset to Equty Ratio

Dari Tabel 5 dapat dilihat bahwa PT. Indocement Tunggal Perkasa. Tbk dan PT. Holcim. Tbk telah dianggap baik dalam menggunakan modal sendiri untuk menjamin hutang jangka panjang karena masih di bawah rata-rata industri.

Tabel 5. Total Asset to Equty Ratio

\begin{tabular}{|c|c|c|}
\hline Tahun & PT. Indocement Tunggal Perkasa. Tbk & PT. Holcim. Tbk \\
\hline 2014 & 1.17 & 1.96 \\
\hline 2015 & 1.16 & 2.05 \\
\hline
\end{tabular}

Sumber : Data yang diolah

3. Fixed Asset to Equity Ratio

Tabel 6 menunjukkan kedua perusahaan telah mampu memaksimalkan penggunaan aktiva tetap. karena berada diatas standar industri

Tabel 6. Fixed Asset to Equity Ratio

\begin{tabular}{|c|c|c|}
\hline Tahun & PT. Indocement Tunggal Perkasa. Tbk & PT. Holcim. Tbk \\
\hline 2014 & 0.52 & 1.70 \\
\hline 2015 & 0.61 & 1.74 \\
\hline
\end{tabular}

Sumber : Data yang diolah

4. Current Asset to Equity

Dari Tabel 7 menunjukkan PT. Indocement Tunggal Perkasa. Tbk dan PT. Holcim. Tbk tahun 20142015 telah dapat memaksimalkan penggunaan asset lancar. karena berada diatas standar industri.

Tabel 7. Current Asset to Equity

\begin{tabular}{|c|c|c|}
\hline Tahun & PT. Indocement Tunggal Perkasa. Tbk & PT. Holcim. Tbk \\
\hline 2014 & 0.52 & 0.26 \\
\hline 2015 & 0.61 & 0.31 \\
\hline
\end{tabular}

Sumber : Data yang diolah

5. Receivable to Equity Ratio

Dari Tabel 8 dapat ditunjukkan bahwa piutang PT. Indocement Tunggal Perkasa. Tbk berbanding modal untuk tahun 2014 dan 2015 sudah cukup baik begitu juga PT Holcim Tbk. kedua perusahaan telah memenuhi rata-rata industri.

Tabel 8. Receivable to Equity Ratio

\begin{tabular}{|c|c|c|}
\hline Tahun & PT. Indocement Tunggal Perkasa. Tbk & PT. Holcim. Tbk \\
\hline 2014 & 0.11 & 0.13 \\
\hline 2015 & 0.11 & 0.14 \\
\hline
\end{tabular}

Sumber : Data yang diolah 


\section{Analisa Ratio Aktivitas}

1. Sales to Receivable

Dari tabel 9 dapat dilihat PT. Indocement Tunggal Perkasa. Tbk untuk tahun 2014 dana yang tertanam dalam piutang perusahaan dalam kondisi cukup baik karena berada diatas rata-rata industri. tetapi untuk tahun 2015 mengalami penurunan drastis dan berada dibawah rata-rata industri. sedangkan PT Holcim Tbk untuk tahun 2014-205 dana yang tertanam dalam piutang perusahaan dalam kondisi cukup baik karena berada diatas rata-rata industri.

Tabel 9. Sales to Receivable

\begin{tabular}{|c|c|c|}
\hline Tahun & PT. Indocement Tunggal Perkasa. Tbk & PT. Holcim. Tbk \\
\hline 2014 & 7.49 & 8.05 \\
\hline 2015 & 1.59 & 7.64 \\
\hline
\end{tabular}

Sumber : Data yang diolah

2. Sales to Current Asset

Dari Tabel 10 dapat dilihat bahwa kedua perusahaan untuk tahun 2014 -2015 dana perusahaan yang tertanam dalam aktiva lancar cukup baik karena berada diatas rata-rata industri. hanya untuk PT Holcim terlalu jauh diatas standar industri akan dapat memberikan dampak negatif terhadap dana yang tertanam dalam aktiva tetap.

Tabel 10. Sales to Current Asset

\begin{tabular}{|c|c|c|}
\hline Tahun & PT. Indocement Tunggal Perkasa. Tbk & PT. Holcim. Tbk \\
\hline 2014 & 1.24 & 4.14 \\
\hline 2015 & 1.36 & 3.58 \\
\hline
\end{tabular}

Sumber : Data yang diolah

3. Sales to Fixed Asset

Dari Tabel 11 dapat dilihat PT. Indocement Tunggal Perkasa. Tbk dan PT Holcim Tbk tahun 2014 2015 dana yang tertanam dalam aktiva tetap cukup baik karena berada diatas rata-rata industri.

Tabel 11. Sales to Fixed Asset

\begin{tabular}{|c|c|c|}
\hline Tahun & PT. Indocement Tunggal Perkasa. Tbk & PT. Holcim. Tbk \\
\hline 2014 & 1.56 & 0.64 \\
\hline 2015 & 1.23 & 0.63 \\
\hline
\end{tabular}

Sumber : Data yang diolah

4. Sales to Total Asset

Dari Tabel 12 dapat dilihat kedua perusahaan pada tahun 2014-2015 dana yang ada dalam total aktiva sudah cukup baik karena berada diatas rata-rata industri.

Tabel 12. Sales to Total Asset

\begin{tabular}{|c|c|c|}
\hline Tahun & PT. Indocement Tunggal Perkasa. Tbk & PT. Holcim. Tbk \\
\hline 2014 & 0.69 & 0.55 \\
\hline 2015 & 0.64 & 0.53 \\
\hline
\end{tabular}

Sumber : Data yang diolah

\section{Analisa Ratio Profitabilitas}

1. Net Profit Margin (NPM)

Dari Tabel 13 dapat dilihat PT. Indocement Tunggal Perkasa.Tbk tahun 2014-2015 berada diatas ratarata industri. yang berarti kinerja keuangannya sangat baik. sedangkan PT Holcim Tbk kinerja keuangannya sangat buruk karena berada dibawah rata-rata industri 
Tabel 13. Net Profit Margin

\begin{tabular}{|c|c|c|}
\hline Tahun & PT. Indocement Tunggal Perkasa. Tbk & PT. Holcim. Tbk \\
\hline 2014 & 0.26 & 0.07 \\
\hline 2015 & 0.24 & 0.02 \\
\hline
\end{tabular}

Sumber : Data yang diolah

2. Return On Investment (ROI)

Dari Tabel 14 dapat dilihat kinerja kedua Perusahaan pada tahun 2014-2015 sangat buruk karena berada dibawah rata-rata industri.

Tabel 14. Return On Investment

\begin{tabular}{|c|c|c|}
\hline Tahun & PT. Indocement Tunggal Perkasa. Tbk & PT. Holcim. Tbk \\
\hline 2014 & 0.18 & 0.04 \\
\hline 2015 & 0.16 & 0.01 \\
\hline
\end{tabular}

Sumber : Data yang diolah

3. Return On Equity (ROE)

Dari tabel 15 dapat dilihat kinerja keuangan kedua perusahaan tahun 2014 -2015 sangat buruk karena berada dibawah rata-rata industri.

Tabel 15. Return On Equity

\begin{tabular}{|c|c|c|}
\hline Tahun & PT. Indocement Tunggal Perkasa. Tbk & PT. Holcim. Tbk \\
\hline 2014 & 0.21 & 0.08 \\
\hline 2015 & 0.18 & 0.02 \\
\hline
\end{tabular}

Sumber : Data yang diolah

\section{KESIMPULAN}

Prestasi kinerja keuangan untuk PT. Indocement Tunggal Perkasa.Tbk sudah cukup baik. hal ini dapat dilihat dari Rasio Likuiditas. Rasio Solvabilitas. dan rasio rentabilitas hanya saja untuk rasio aktivitas saja pada PT Indocement Tunggal Prakarsa Tbk dapat dikatakan sudah baik. Sedangkan prestasi kinerja keuangan PT. Holcim.Tbk masih kurang baik. hal ini dapat dilihat dari Rasio likuiditas. rasio solvabilitas dan rasio aktivitas. sedangkan untuk rasio rentabilitas masih sangat buruk.

\section{SARAN}

PT Indocement Tunggal Prakarsa terus mempertahankan kinerja yang telah ada dan ditingkatkan lagi terutama dalam memanfaatkan aktiva lancarnya.Untuk PT Holcim Tbk dilihat dari rasio likuiditas harus lebih pandai dalam mengelola kas perusahaan agar nantinya dana/modal perusahaan dapat digunakan untuk membayar hutang perusahaan.

\section{DAFTAR PUSTAKA}

Hanafi dan Halim 2009. Analisis Laporan Keuangan.. Unit Penerbit dan Percetakan Sekolah Tinggi Ilmu Manajemen YKPN. Yogyakarta

Harahap 2006. Keunggulan Rasio Keuangan. Diakses 19/09/1012. http://www.scribd.com/doc/59417382/definisi-rasio-keuangan

Harahap 2008. Analisis Kritis atas Laporan Keuangan. Diakses 19/09/2012. http://elib.unikom.ac.id/files/disk1/537/ibptunikompp-gdl-anggitarac-26828-5-unikom_ai.pdf

Kamaludin dan Rini 2012. Manajemen Keuangan. Penerbit CV. Mandar Maju. Bandung Kasmir 2008. Analisis Laporan Keuangan. Penerbit PT. RajaGrafindo Persada. Jakarta 